\title{
Beyond Localism: The Micropolitics of Local Legitimacy in a Community-Based Organization
}

\author{
Olivia Molden ${ }^{\mathrm{a}}$, Jesse Abrams ${ }^{\mathrm{b}}$, Emily Jane Davis ${ }^{\mathrm{c}}$, and Cassandra Moseley ${ }^{\mathrm{b}}$ \\ ${ }^{\mathrm{a}}$ Department of Geography, University of Oregon, 107 Condon Hall, Eugene, OR USA 97403- \\ 1251 omolden@uoregon.edu \\ ${ }^{\mathrm{b}}$ Institute for a Sustainable Environment, University of Oregon, 130 Hendricks Hall, \\ Eugene, OR USA 97403-5247 jabrams@uoregon.edu; cmoseley@uoregon.edu
}

${ }^{c}$ Department of Forest Ecosystems and Society, Oregon State University, 321 Richardson Hall, Corvallis, OR USA 97331 emilyjane.davis@ oregonstate.edu

Corresponding Author: Jesse Abrams, jabrams@uoregon.edu, Ecosystem Workforce Program, University of Oregon, 130 Hendricks Hall, Eugene, OR USA 97403-5247

\section{Introduction}

The scope of action of local and regional non-governmental organizations (NGOs) has increased with the shift from hierarchical (state-led) government to multiactor networked governance in many countries (Edwards and Hulme, 1995; Falkner, 2003; Newell et al., 2012). Neoliberal processes of "rolling back" the state and "rolling out" a variety of hybrid governance mechanisms (Peck and Tickell, 2002) have opened opportunities for NGOs to take on expanded roles in community development, planning, natural resource conservation, and related tasks traditionally performed by governments (Buscher, 2010; Fredericksen and London, 2000; Hodge and Adams, 2012; Marwell, 2004; Parkins et al., 2016). The ascension of NGOs as leaders of conservation and development processes has sparked a critical debate regarding questions of the legitimacy and accountability of non-state actors (Brosius et al., 1998; Connelly et al., 2006; Edwards and Hulme, 1995; Lane and Morrison, 2006). These questions have become particularly salient given the "blurring" of state and non-state roles in devolved governance (Newell et al., 2012).

Shifts in environmental governance have revitalized the focus on communities in geography and allied disciplines. This has brought attention to the emerging networks of discourse and action that are spatially rooted at the community scale and take as their charge the governance of the local social and natural environment (e.g., Cheng et al., 2015; Healey et al., 2003; Larner and Craig, 2005; Lockie and Higgins, 2007; Uphoff, 1993). In the U.S. West, this is seen most prominently in literature on place-based collaboration and community forestry, which are framed as participatory and grassroots alternatives to the technocratic and top-down planning institutions that have dominated environmental management and rural development (Baker and Kusel, 2003; Brick et al., 2000; Gray et al., 2001; Kusel and Adler, 2003; McCarthy, $2005 ; 2006)$. While the bulk of this scholarship has focused on the procedural aspects of inclusive multi-stakeholder collaboration (e.g., Conley and Moote, 2003; Daniels and Walker, 1996; Margerum, 2011; Wondolleck, 2000; Yaffee, 1994), processes of network governance in 
rural places also include the development of a substantial community-based NGO sector that is worthy of closer analysis. Indeed, a network of community-based organizations (CBOs) is arguably responsible for catalyzing substantial institutional change in furtherance of a community forestry model in a number of communities across the West (Abrams et al., 2015; Danks 2008; Enzer and Goebel, 2014).

As locally rooted "bridging organizations" (Berkes, 2009; Brown, 1991; Cash et al., 2003; Crona and Parker, 2012; Hahn et al., 2006), CBOs may be capable of catalyzing improvements in rural development and conservation while avoiding some of the pitfalls of centralized and top-down managerial forms (Westley, 1995). A key component of this kind of work is legitimacy, "a sense that an organization is lawful, proper, admissable and justified in doing what it does and saying what it says, and that it continues to enjoy the support of an identifiable constituency" (Edwards, 1999, p. 258). In many cases, NGOs derive their legitimacy specifically from their ability to act effectively where states have failed to do so (Collingwood, 2006). Moreover, NGOs derive significant benefit from the "discursive legitimacy" (Hardy and Phillips, 1998; Purdy, 2012) bestowed upon them due to their ability to represent social groups or interests deemed important in popular discourse. Yet relatively little scholarship specifically queries how community-based NGOs establish and maintain legitimacy among community members and organizational leaders in the regions they serve. This "local legitimacy" is a potentially complex concept in communities of the rural U.S. West, which have undergone substantial economic restructuring (Nelson, 2001) and demographic turnover (Winkler et al., 2007) and which remain riven by competing narratives of past and future development (McCarthy, 2002; Walker, 2003). Questions of legitimacy may also be bound up in negotiating diverse cultural and material differences between the 'rural' and 'urban' that in turn shape economic activity, the landscape, and lived experiences (Hiner, 2016). Here we investigate the micropolitics of local legitimacy among the Glenwood, Washington-based CBO Mount Adams Resource Stewards (MARS) and the former timber-dependent community in which it works through the CBO's relationships with residents and with other organizations relevant to the social, political, and economic life of people in the region. We argue that dimensions of interpersonal relations, local narratives, and demonstrations of effectiveness were crucial to both the organization's local legitimacy and, ultimately, its license to lead community development efforts. At the same time, larger structural constraints continued to weigh on the ability of these efforts to achieve a lasting transformation in the community's developmental trajectory.

\section{The Rise of Community-Based Organizations in Rural Development and Natural Resource Management}

As rural bridging organizations, CBOs have been key but, to date, understudied actors in community-based conservation and development in the U.S. West (Danks, 2008). We define CBOs here as grassroots NGOs that work at multiple scales to achieve natural resource-based rural development in historically resource-dependent communities (Abrams et al. 2015). These organizations emerged in specific geographies across the West to help navigate the transition to what has been called a "new natural resource economy" (Hibbard and Lurie, 2013) based on sustainable environmental management practices and associated economic development. The emergence of CBOs in the rural U.S. West parallels a global trend in the rise of non-profit and non-governmental organizations, which regularly work in historically marginalized areas to fill gaps in public services (Corson, 2010; Marwell, 2004; Takahashi and Smutny, 2001). In the United States and Canada, government promotion of community forestry reflects a trend in the 
devolution of state-centered control over natural resources to facilitate local participation in conservation and rural development (Glasmeier and Farrigan, 2005; McCarthy, 2005; 2006; Parkins et al., 2016).

Numerous structural issues associated with the persistence of governmental and corporate domination of resources challenge efforts to facilitate just and effective community-based natural resource based development in many rural areas (Alexander, 1999; Fernandez-Gimenez et al., 2008; Parkins et al., 2016; Takahashi and Smutny, 2001). Prior research has examined how community-based resource management projects, particularly those run by external actors, can risk further marginalizing rural populations by exacerbating inequalities or entrenching poverty, often citing 'elite capture' as an issue (Berkes, 2004; Blaikie, 2006; Glasmeier and Farrigan, 2005; Mansuri and Vijayendra, 2004; Marfo, 2007). More generally, challenges such as poor external support, increasing commodification and privatization, a lack of true devolution, weak local institutions, and a lack of capacities or resources in communities limit the potential of community-based efforts (Armitage, 2005; Blaikie, 2006; Gruber, 2010; Leach et al., 1999). Moreover, after decades of rural resource extraction and marginalization, recent policy reforms promising community participation often meet rural populations "weary and wary of any further interventions by the government" (Blaikie, 2006, p. 1943).

Despite these tensions and constraints, locally based NGOs have shown some success in resolving longstanding resource conflicts, representing diverse community interests to higherscale decision-makers, empowering traditionally disempowered actors, and facilitating the delivery of local economic and environmental benefits (Arcand and Wagner, 2016; Barr et al., 2015). For example, to enhance the wellbeing and security of the interests they serve, CBOs may fill institutional gaps at the local level and create linkages across multiple scales and sectors to generate opportunities for local resource users (Abrams et al., 2015). Here, CBOs look inward to attend to the diverse needs of their rural communities and simultaneously reach outward to navigate the various - and often conflicting - interests of government agencies, corporations, and other non-governmental groups that commonly have vested interests in public lands and resources (McDermott et al., 2011; Cheng et al. 2015). In contrast to the rigid bureaucratic arrangements of large-scale governmental and non-governmental organizations, CBOs may have the potential to act in a more flexible and adaptable manner (Brown, 1991; Crona and Parker, 2012; Westley, 1995). However, as organizations rooted at the community scale, their ability to act is contingent upon the establishment of strong local legitimacy (Hashemi and Hassan, 1999; Pratten and Ali Baldo 1995; Walker and McCarthy, 2010).

\section{Local legitimacy as a key concern for CBOs and place-based NGOs}

Legitimacy is a multifaceted concept defined here following Suchman (1995, p. 574) as "a generalized perception or assumption that the actions of an entity are desirable, proper, or appropriate within some socially constructed system of norms, values, beliefs, and definitions." The literature on NGO legitimacy encompasses a wide span of definitional criteria, ranging from apolitical measures of market efficiency to more explicitly political measures of structural change (Atack, 1999; Thrandardottir, 2015; Vedder, 2007). In spite of the expansive literature on NGO legitimacy, Lister (2003) observes that analyses often fail to specify to whom an organization must establish its legitimacy; existing scholarship typically adopts the implicit gaze of national- and global-level funders, states, and other actors rather than that of the local community. Yet, "the consent or representation of those involved or affected" (Vedder, $2007 \mathrm{p}$. 7) is inarguably a key dimension of NGO legitimacy, particularly for those parties claiming to 
represent communities of place. While similar concepts like a company's 'social license to operate' in rural resource dependent communities reflect the necessary work of gaining trust and consent from 'local residents,' it is clear that local residents and organizational and firm representatives encompass a variety of ideas and desires that are not homogenous (Cheshire, 2010; Lähtinen et al., 2016; Moffat and Zhang, 2014). Moreover, in landscapes affected by shifting governance arrangements, NGOs typically must reach beyond the local scale to build legitimacy with interests across the broader region.

Several authors have recognized the dilemma of "multiple accountability" (upwards to funders and states and downwards to local communities) of place-based NGOs (Edwards 1999, Edwards and Hulme 1995, Saxby 1996). In spite of the problematic nature of concepts like "local" and "community" (Agrawal and Gibson, 1999; Blaikie, 2006; Lane and Corbett, 2005; Ojha et al., 2016), the symbolic power of "localism" is widely recognized to be a contributor to the legitimacy of rural organizations and initiatives (Hurley and Walker 2011; Pratten and Ali Baldo 1995). Yet relatively little scholarship explicitly attempts to trace the work of NGOs in generating and maintaining legitimacy to local stakeholders such as citizens, private businesses, and other established organizations. In this paper, we raise the question of what local legitimacy means and how it is negotiated by a CBO engaged in work to institute community forestry in the rural U.S. West. We employ a micropolitical analytic, attending to the local-scale interactions and dynamics that are strongly implicated in the success of community-based initiatives (Healey et al., 2003). We pay particular attention to the role of narratives, which may be central to building a kind of "discursive legitimacy" (Hardy and Phillips, 1998; Lister, 2003; Purdy, 2012) and to the recursive relationships between practical outcomes and legitimacy that have been observed in prior scholarship (e.g., Abers and Keck, 2013).

\section{Methods}

This research draws on semi-structured interviews from a case study of Mount Adams Resource Stewards (MARS), a CBO dedicated to a community forestry approach to local conservation and development in the rural region near Mount Adams, Washington. We base our analysis primarily upon data from sixteen in-depth interviews in 2012 and a later follow-up interview in $2016^{1}$. Four interviews, including the more recent follow-up, were conducted with MARS staff and thirteen with representatives from various partner organizations working in other local and regional non-profit organizations, private businesses (including local landowners), and local, state, and federal government entities. While interviews focus on locally embedded leaders, several of these interviews took place with individuals not originally from the region. Most, but not all, considered themselves to be Glenwood community members or part of the 'local' community of the greater Mount Adams region. Interviews queried the history and purpose of the $\mathrm{CBO}$ as well as its activities, outcomes, challenges, and relationships to other organizations and to the local community. Supporting documents related to MARS and the Mount Adams region, such as news articles and website postings, were also collected and analyzed. Additional insights were gained from over a decade of ongoing professional connections and collaborations between MARS and several of the authors of this manuscript ${ }^{2}$.

The research team employed a structured, iterative interpretive process informed by grounded theory methods to analyze the interview data (Bowen, 2006; Charmaz, 2006; Suddaby, 2006). We utilized multiple rounds of "open" and later "closed" coding to develop broad categories and themes from the data and to generate additional hypotheses and questions. We also generated voluminous interpretive summaries (memos) to build an interpretive "scaffolding" 
and provide the basis for a comprehensive narrative (Emerson et al., 1995). Throughout, we took an explicitly micropolitical approach to interpreting our data. A micropolitical perspective brings to light the way power operates through everyday practices and interactions among people at the local level, which can be revealing of the ways in which individuals subvert or reinforce larger institutional influences (Mcareavey, 2006; Smeed et al., 2009). A focus on the everyday 'nittygritty' interactions that make up larger projects provides a grounding to understand how rural development unfolds, and more specifically, how a small place-based organization materializes its vision for development (Stoddart, 2005). We present our results as an initial exploration of the theme of local legitimacy in community-based NGOs, acknowledging the need for continued research in more locations and with a wider variety of potential stakeholders.

\section{Results}

We present results from this grounded theory analysis chronologically, starting with a historical background on the area in which MARS operates, followed by an account of its community forestry efforts within the context of questions of local legitimacy. We focus on evidence of micropolitical processes to analyze the ways in which this organization worked to achieve local legitimacy, focusing on the relational, discursive, and practical dimensions of the CBO's efforts.

\subsection{The Mt. Adams region in the context of Pacific Northwest Forestry}

MARS, founded in 2003, is based in Glenwood, Washington (population estimate 500), an unincorporated former "timber town" in Klickitat County in southern Washington State near the Cascade peak of Mt. Adams. As an organization that attempts to achieve linked social, economic, and environmental improvements in a particular locale through work at multiple scales, MARS shares much in common with a suite of CBOs across the rural U.S. West (Enzer and Goebel, 2014). Despite being diverse in scope, focus, capacity, and organizational characteristics, these organizations generally share an emphasis on catalyzing local development trajectories toward equitable natural resource-based economic development centered on ecological restoration and stewardship within parameters deemed acceptable by diverse stakeholders (Hibbard and Lurie, 2013; Kelly and Bliss, 2009). Their activities take place in the context of a pattern of heightened conflict, increased localized rural poverty, and the breakdown of longstanding public and private environmental management institutions in the U.S. West since the 1990s.

The federal government, via the Gifford Pinchot National Forest and the Conboy Lake National Wildlife Refuge, and the Confederated Bands and Tribes of the Yakama Nation own the majority of the land in the Mt. Adams area. The rest is largely composed of industrial (or formerly industrial) timberlands, private farmlands, and forestlands owned by the State of Washington. The Collins Companies controlled much of Klickitat County's private timberland in the early twentieth century, and later years saw occasional sales to other vertically integrated wood products businesses. Throughout the postwar years, management styles on private and federal forests here and nationwide converged around an intensive production model designed to grow and extract high-value wood fiber quickly and efficiently (Hirt, 1994; Power, 2006). From the perspective of federal forest managers and their allies in Congress, this model supported rural economic development and "community stability" via the provisioning of timber-related employment in the woods, in transportation, and at local mills (Moseley and Charnley, 2014). 
The economies and cultures of communities such as Glenwood grew increasingly intertwined with intensive forest production on private and public timberlands.

The close relationship between rural economic activity and local forestlands was thrown into disarray at the close of the twentieth century and beginning of the twenty-first as a result of four separate dynamics. First, conservation- and preservation-oriented activists mounted successful legal challenges to the intensive timber production model on federal forestlands. This triggered a sudden shift in management policy to privilege endangered species and natural ecosystem quality over wood fiber production (Cashore and Howlett, 2007; Yaffee, 1994), resulting in an $80 \%$ reduction in federal timber harvest (Power, 2006). On private forestlands, many of the formerly vertically integrated companies restructured in the late 1990s and 2000s to take advantage of tax benefits and burgeoning real estate markets. These dynamics triggered rapid turnover in private forest ownership as new investors entered the market to capitalize upon these newly liquid assets and capture associated short- and medium-term profits (Bliss et al., 2010). Third, changes to technology and capital-labor relations reduced the community economic benefits associated with timber production and further exacerbated economic insecurity in many rural areas of the U.S. West (Prudham, 1998). Layered on top of these economic and policy changes was the phenomenon of amenity migration, in which scenic rural locales like the Mt. Adams area became highly sought-after by urban retirees, telecommuters, and second-home owners (Gosnell and Abrams, 2011). Glenwood and its environs felt the full brunt of these changes. Timber harvesting on the Gifford Pinchot National Forest ground to a halt in the wake of the shift to ecosystem management and 80,000 acres of the private forestland base was sold to a timber investment management organization (TIMO) that began to manage according to a short-term investment horizon. Several, mostly urban-based, NGOs made their influence felt on public and private land environmental management in Klickitat County. Parts of Klickitat County began to attract urban migrants and retirees, further increasing development pressure on what were once production-oriented forestlands.

It was within this context that MARS, whose mission is to "promote sustainable connections between the land, local economies, and rural communities in the Mt. Adams Region," was founded to build a community forestry program from the ground up. The organization was founded by a single individual (who was the organization's only staff member for many years) with moral support from local leaders and financial support from a mix of local and nonlocal sources. Key elements of MARS' program to date include planning and implementing forest restoration projects across a mixed-ownership landscape, co-leading a collaborative process for building agreement on management actions on the southern portion of the Gifford Pinchot National Forest, providing planning and management services to small forest owners and land trusts, maintaining a small-diameter timber utilization site where two businesses have located, and, most prominently, establishing a community-owned forest on former industrial timberlands. Added to these are numerous smaller projects such as establishing a community garden at the local public school, conducting educational and outreach activities, working to expand broadband Internet connectivity to underserved portions of Klickitat County, and maintaining a website that connects local forest contractors to landowners in search of management services. These activities are conducted with a small staff that has grown to as many as three individuals, with key roles played by community partners outside the organization.

MARS' achievements reflect the human capital of its staff as well as structural aspects of the organization, such as its registered nonprofit status that makes it eligible for a variety of grant 
funding. Through our research, we found that building local legitimacy was also crucial to MARS' efforts, as it allowed the organization to amass both the financial and social capital necessary to be effective. The analysis that follows describes the contours of local legitimacy as they affected the activities of MARS as an organization and of its staff and community partners. Key dimensions include the legitimacy of individuals, the legitimacy of MARS as an organization, and the legitimacy of the larger community forestry narrative that represented a vision for rural development in this particular place. All three were strongly dependent upon a grounding in the "dominant discourses" (Lister, 2003) of local community history and identity. The outcomes that MARS achieved were, in turn, both the result of building this local legitimacy and a resource for generating increased legitimacy.

\subsection{The Legitimacy of Organization Leaders: Identities and Interpersonal Relationships}

As is true for many development-oriented NGOs, the founder and executive director of MARS was not himself originally from the area the organization serves. This raises the question of how an individual without strong local ties is able to generate the kind of local acceptance necessary to work effectively through a CBO. Interviews with longstanding local leaders regularly referred to several characteristics that allowed a relative "newcomer" to gain the local legitimacy needed to lead a community effort. These included the individual-level characteristics of charisma, trustworthiness (at least some of the latter due to his tenure as a local schoolteacher and his participation in the advisory "community committee" of Glenwood), and formal knowledge stemming from an advanced degree from the prestigious Yale School of Forestry and Environmental Studies. The founder and director also generated individual legitimacy by earning the endorsement of symbolically and politically important local actors; one local government official expressed that the local "farmers and ranchers" all held positive opinions of the MARS director, which led the official to provide both moral and government financial support. Beyond the strictly individual-level legitimacy garnered by the founder and director, interviewees referenced the fact that the MARS board of directors contained several "locals" (meaning longterm residents of the area with roots in traditional productivist land uses), which was considered important because "people don't like to be told what to do from afar."

The community forestry program forwarded by MARS was lent credence and effectiveness through numerous individual-scale relationships with the founder and director; indeed, many interviewees used the organizational name and the director's name interchangeably when discussing MARS' work. These relationships included not just local elected officials, business owners, and wood products workers, but also local representatives of state and federal agencies and regional NGOs, at least some of whom were themselves longstanding members of the Glenwood community. One agency manager in particular related his interest in working as much as possible with the MARS director because of a personal trust in the director himself, respect for his skills and knowledge, and affinity for MARS' linked conservation and development vision. While this manager did not act outside the scope of his official duties, he did express personal commitment to seeing MARS' community forestry vision succeed and reported searching for ways to support MARS' involvement in management projects - an outcome that also provided benefits to the agency due to the efficiencies involved in working with a knowledgeable and flexible local organization. Through this relationship, MARS was able to generate local economic activity, put local contractors to work, and demonstrate the ecological outcomes of progressive forestry practices. 
Thus, the relationship between individual- and organizational-level legitimacy and effectiveness was reciprocal; as MARS and its staff gained greater levels of trust and credibility they were better able to demonstrate tangible outcomes. In some cases, these demonstrated outcomes were well outside the scope of a community forestry program (e.g., expanding broadband Internet and installing a community garden at the local school) that nevertheless demonstrated a commitment to community development writ large. In other cases, outcomes were the result of working partnerships established with government agencies, non-local NGOs, and other organizations. Interpersonal relationships and a shared commitment to forest stewardship and economic development led to a program of work on public lands that provided job opportunities for local contractors and forest products for local mills.

In such cases, the micro-scale relationships and legitimacy built through everyday processes opened access to forest management opportunities that served to demonstrate practical outcomes. Such projects helped to build the legitimacy of MARS as a whole, further increasing its effectiveness. This virtuous cycle had its limits, however; frequent turnover in federal agency positions placed a strain on the heavily relationship-based work conducted by MARS. One government employee explained how their previous supervisor supported MARS and the MARS mission but was replaced by another who had different ideas, and so "institutional knowledge gets lost...Understood agreements don't necessarily carry over into the new management structure." Relying on individual relationships proved to be risky, even when there appeared to be mutual understanding and support. For example, when discussing the success of a recent project, the MARS director explained that the project's success "probably could change at the drop of a hat if you had some different staff in [the partner organization]." As a result, the organization's work has "been like a hot spot approach. It's like you go where people get it and request cooperation, so it's happened in some geographies much better than others." Some interviewees expressed concern about the fact that so much of MARS' success was wrapped up in a single individual, creating potential vulnerabilities for long-term success.

\subsection{Organizational Legitimacy: Responding to Narratives and Proving Results}

Respondents frequently contrasted MARS' organizational approach to grassroots, community-based development with the approach taken by other non-local NGOs and actors. At the end of an extended critique of the influence of non-local environmental organizations and associated lawsuits on the local economy, one local government official related:

[The environmental activists] are the kind of people that aren't welcome, the kind of people that nobody wants to see coming in to this county and [the MARS director is] the kind of people that they do want to see. He's actually coming in and doing something and being a good steward of the land, being a good friend and being a responsible citizen and being an all-around good person who really, truly cares about the environment and is trying to do something with it.

From this perspective, non-localness is not, in and of itself, perceived negatively; rather, it is the influence of non-local actors who fail to consider community interests and values that is cast in a negative light. What appeared to be most important to this individual was that the MARS staff and board had acknowledged a community narrative in which longstanding economic activities that had provided identity and prosperity had been suddenly taken away, and further that MARS had worked with local people to help address these concerns. The dominant local discourse was not simply a familiar narrative of environmentalists shutting down timber harvesting; it was also 
a narrative about the economic and environmental insecurity that came with the demise of the traditional vertically-integrated timber companies and the rise of the TIMOs. Indeed, the twin anxieties about the influence of "outside" environmental advocates and the effects of timber industry restructuring and divestment permeated our interviews, and it is in this context where support for a community-based forest management narrative showed potential.

Most of MARS' early work centered on helping local people gain in-woods and manufacturing work from restoration projects on nearby state and federal forestlands. However, beginning in 2006 the director began to explore with local and non-local partners the idea of a community-owned forest on former industrial land. Following some initial progress, the project became ensnared in controversy when a widely read magazine article was published in the popular news magazine High Country News (Little, 2006). The article pitted the community forestry approach of MARS against the activities of Hancock Forest Management, the Bostonbased TIMO that had recently purchased local timberlands. The article raised concerns regarding the company's purchase of remaining private timberlands in the area, hiring outside workers, aggressively cutting local forests, and selling logs to external markets. The story upset Hancock managers, who said they had been portrayed as not caring about the community. As part of the fallout from the article, Hancock fired a local timber contractor who was also a MARS board member. The MARS director had to mend relationships with Hancock and explain that much of the article was not a fair representation, eventually leading to the re-hiring of the contractor and board member. By losing control of the community forestry narrative, MARS' efforts were dealt a setback.

For several years following the High Country News controversy, MARS refocused on job creation and on a woody biomass project with the nearby Gifford Pinchot National Forest, keeping conversations about community-owned forests internal to the organization. Convincing skeptical board members and community leaders to support the concept of a community-owned forest was ultimately bolstered by a field visit to community-owned forests in New England; the tour was made possible through the director's contacts with community forestry representatives in that region of the country. The visit demonstrated the practical benefits to arise from community-owned forests and suggested that such an idea was not simply a false hope for Glenwood. This move was key to building local support for establishing a community forest and ultimately enhancing organizational legitimacy. According to a participant who went on this field trip:

...that was the first time that I really got to spend a lot of time with [the director] and got to know more of what the group is doing...it was just really eye-opening for most of us who come from the West where it's a lot of private land or federal and state, but there's not a lot of that local county-owned or town-owned property that's managed in that way.

The director used personal professional networks from outside the community to build support for projects within the Mt. Adams region. Such connections with organizational representatives allowed the director to breathe new life into a community forestry narrative that had previously been drowned out by the High Country News controversy.

In the meantime, community meetings, flyers, newsletters, school programs, and the successful implementation of both forestry and non-forestry projects in the local area facilitated the building of awareness and support among the broader community. However, many respondents explained that most local people doubted that the organization could actually raise 
enough money to purchase local timberlands and convert them into a community forest. As the MARS director explained,

I think most people thought it wasn't probably the most realistic idea or you know, boy, that land sold for eighty million dollars or whatever the price tag was, how's a little community, a place like this, ever going to be able to intervene or insert themselves into that process and come up with enough capital to actually own some ground?

Despite what appeared to be an impossible task, MARS looked to local people to support the community forest vision financially. Numerous, and sometimes substantial, donations were made from community members to acquire a 100-acre parcel known as the Mill Pond site in 2011. Individuals and organizations from the broader region with local ties also made donations, including the Collins Family, the historic landowners of the property. While some outside funds were also brought in, a majority of the financing for the forest came from the local areaincluding, in some cases, from individuals who had earlier expressed skepticism about MARS' vision. Many interviewees felt that MARS' greatest success as an organization was its ability to purchase the Mill Pond tract. For example, one interviewee was impressed by "the fact that they were able to pull off, what I consider, a pretty large acquisition with the Mill Pond, that shows that they're committed and they have the ability to get large chunks of forest to turn into community forestry." This success was followed up in 2014 by the purchase of a separate, 285acre site known as Pine Flats.

MARS' effectiveness in acquiring community-owned forests contributed greatly to its local legitimacy. The concept of community-owned land took hold in a place where people had felt betrayed by the legacy of both government and corporate forest management. In fact, nearly all interviewees expressed some complaints regarding the government programs working in the area, raising specific concerns about things such as budget and staff cuts, reliance on public grant funding, poor public engagement and knowledge-sharing on the part of federal managers, the complexity of the federal bureaucracy, and lack of proactive forest management. Thus, work promoting local autonomy was key, particularly through tangible outcomes such as the land acquired, or timber sold and employment gained. As one local forester explained,

I think the other thing that was important too, was that [Mill Pond] would not be, in the case of the community forest, would not be a, 'publicly run forest,' that it was managed more independent and could use state of the art techniques, rather than being forced to do certain things based on political pressure.

Another local forester explained how the community forest:

...provides jobs for here, it doesn't tie things up in court cases...it's almost impossible to get any timber off the Forest Service... [the community forest is] a land base that can help provide jobs into the future, but yet not restricted by public policy.

Community-owned forestland thus represented a move towards local longevity, ownership, autonomy, and independence in favor of local economic opportunities while providing both symbolic and material continuity with the dominant identity and discourse of the rural timber town.

A combination of prior experience, charismatic leadership, and diverse strategies to connect with local leaders and residents allowed MARS to recognize structural limitations, build on local discourses and sentiments, and craft an alternative route for local development. 
Cognizant of the frustrations surrounding land management, the organization employed a discourse and strategy of local ownership for the community forestry effort, feeding back into local desires for greater political independence and historic identities bound to "working lands." Behind the scenes of the organization's success were the everyday conversations with residents, phone calls with other local leaders, and other interpersonal interactions that occurred both formally and informally. These micropolitical dynamics at the individual level helped establish MARS as a credible organization with the potential to make change. The materialization of the first community forest as an actual parcel of land was a significant moment in building both the director's - and MARS'-legitimacy, thereby opening opportunities for future projects and connections to prove the organization's effectiveness in making change.

\subsection{The Legitimacy of the Vision: Addressing Structural Constrains on the Ground}

MARS was able to build a community forestry program from the ground up by building trust and legitimacy, demonstrating effectiveness, and providing a discursive alternative to the narrative of dependence upon — and betrayal by - government and corporate forest managers. However, larger structural constraints placed limitations on the organization's reach. Like many small organizations, MARS and its partner organizations identified funding as the CBO's greatest challenge. Although MARS had been successful in attracting grant funding, it had also come to rely heavily upon local business opportunities, such as timber sales and restoration contracts. Some local interviewees saw grant funding as a quintessential government resource and therefore both unreliable and morally suspect. At the same time, MARS perceived an existential threat in its long-term funding status given the limited nature of available restoration contracting, limits to acquiring divested forestland, and limits to the amount of wood volume that could be sustainably produced from the community forest. Additionally, the restoration and stewardship model operates within markets that are dominated by much larger firms and higherscale trade relations. As respondents explained, it is expensive to haul relatively low-value timber to the right markets and find appropriate value-added opportunities. Local labor and capacity to fill certain roles beyond logging and restoration were also often lacking. For example, MARS staff explained how they had difficulty finding local people with an entrepreneurial spirit and innovative ideas to help take over or manage certain projects.

At the same time, even MARS' most successful forestry projects could only serve to complement, rather than substitute for, the existing local reliance on corporate and federal timberlands. A federal agency employee explained how MARS' promotion of working forests may provide additional opportunities to local contractors and mills, but that the local economy remains dominated by larger players:

...sometimes just getting some local operator to work for two months, you know, while we have a lag time in sales, while Hancock has a lag time-[the MARS director] can fill in that gap, that might be the difference. The margins for these operators are really, really slim in terms of survivability. If [the MARS director] can keep them working for two months out of a year, that keeps them around.

The potential of personal relationships to catalyze structural change was also somewhat limited. For example, although local governmental employees expressed personal support for MARS' mission, they were typically constrained in their ability to deviate from institutional procedures. One governmental official explained that their agency's bureaucratic structure placed limitations on the latitude for adaptability and partnership-building: "I can't just call up the people in [the 
capital] and say, 'yeah, [the MARS director] says don't worry about it, it's handled..." Such a reliance on personal connections put a strain on governmental officials, where supporting MARS could be seen as a conflict of interest. At the same time, these interpersonal relations with individuals working in other larger organizations were crucial to the work of MARS and its ability to build local legitimacy through generating practical outcomes.

\section{Discussion: The Micropolitics of Gaining Local Legitimacy}

The analysis of this case highlights an important but understudied dimension of NGO legitimacy - the legitimacy bestowed upon the organization by local citizens and leaders whose consent and support are essential to successful community development. In the case of the Glenwood, Washington area, the dominant discourse was of a formerly prosperous timber town that had its options taken away one by one as federal land management became paralyzed by conflict, its industrial forestlands became newly liquid financial assets, and its landscape became colonized by various "outsiders" who did not take the time to understand local perspectives. In this context, MARS was able to gain legitimacy by providing a narrative that acknowledged this discourse while also providing an alternative pathway forward and by demonstrating that community-centered development could be realized through successful project implementation. This track record of success was ultimately grounded in a multitude of local-level relationships with elected officials, landowners, businesspeople, government agency employees, and others who helped shape a compelling discourse for MARS and provided resources such as access to projects, connections to local agencies and organizations, and monetary donations. As MARS gained legitimacy it was increasingly able to demonstrate effectiveness, thereby underwriting the community forestry narrative. In a community that was "weary and wary" (Blaikie, 2006) of government plans and regional non-profit organizations, MARS was able to build community support through close attention to micropolitical dynamics.

MARS' 'local license to organize' on behalf of the community arose from multiple interrelated sources and was also challenged by multiple constraints (cf. Cheshire, 2010). We underscore the importance of individual relations, grounded yet aspirational narratives, and demonstrated effectiveness as three key and mutually reinforcing components of local legitimacy in this case. While MARS, as an exemplar of a class of CBOs of relatively recent origin, can clearly trace its emergence to larger structural forces that operate at national and even international scales, it remained deeply dependent upon individual relationships for its success. The relationships and credibility of individual members of MARS' staff and board - and particularly of the founder and director that serves as the "face" of the organization to the local community - were crucial in building connections with a variety of local and non-local actors. These relationships themselves generated moral legitimacy (as in the case of local elected officials), opportunities to demonstrate effectiveness (as with local representatives of agencies that control access to forestlands), and opportunities to bolster particular narratives (as in the case of the visit to community-owned forests in New England). Despite MARS' access to grant funds and other resources, it was ultimately reliant for its project implementation upon networks forged through myriad micro-scale actions of relationship building (Mcareavey, 2006).

The projects forwarded by MARS did not stand on their own; rather, they took shape as part of a larger community forestry narrative that posited local ownership and local leadership as achievable and empowering in the face of recent economic and social crises. Importantly, this narrative was not imported wholesale from the outside. While the broad community forestry concept embraced by MARS was undoubtedly the product of larger-scale practice and 
scholarship, its specific details took root within the particulars of the Glenwood community and its own dominant narratives regarding the relationships between local people, nearby resources, and nonlocal forces of change. By understanding and acknowledging these narratives, MARS was able to incorporate them into a discourse that remained locally rooted while offering a more aspirational vision of the relationships between people and forests. MARS was not always able to maintain control of this narrative, as exemplified by the High Country News scandal.

However, strong local-scale relationships forged by MARS staff and board members allowed the organization to heal the damage done and eventually re-engage the community on a contentious issue.

The ultimate test of the community forestry narrative was the demonstration of practical results. These came in both small and large forms, and in some cases were not specifically tied to natural resource issues but nevertheless demonstrated tangible community benefits. A track record of proven outcomes in the form of new local infrastructure, jobs for local contractors, logs flowing to local mills, and well-stewarded local forests worked to generate legitimacy for the community forestry vision and for MARS as an organization. The generation of practical outcomes helped to win over skeptical people and generate further material support. Indeed, what was perhaps the clearest example of the local legitimacy built by MARS came in the form of individual monetary donations by local residents, many of them of modest means, in support of a community-owned forest. Yet, despite these successes, the latitude for local-scale action and relationship building to generate locally legitimate development faced limitations in the face of larger institutional challenges. These limitations were placed as much by the continued control of private forestlands by corporate actors as by the continued control of public lands by bureaucratic actors.

A common thread among all of these aspects is the role of bridging (Berkes 2009; Brown, 1991). The attention to local identities and perceptions in place meant that MARS leaders could create a locally rooted and inclusive narrative for the organization while also acting at extracommunity scales to catalyze local change. Moreover, the ability of the organization to realize this vision, despite the odds, helped establish its local legitimacy. In fact, as MARS grew its network and credibility many respondents from partner organizations indicated that they came to rely on MARS as an intermediary between groups with historically constrained relations. Such work illustrates how local legitimacy necessitates interaction in the rural-urban interface, which includes the various cultural imaginaries of those spaces as well as their physical realities (Hiner, 2016). To effect change in a rural community embedded in a national and global economic and demographic context (Ojha et al., 2016), MARS had to ground its multiscalar work in the discourses, interests, and relationships of the local. However, many such networks rest on the micro-scale interactions and relationships of individuals, like the MARS director, who also carry a great amount of organizational authority and legitimacy as well as networks at multiple scales. Thus, such a reliance on individual leaders illustrates the tenuous nature of local legitimacy (Berkes, 2009; Bodin and Crona, 2008; Datta, 2007; Mountjoy and Seekamp, 2013).

MARS' success in building legitimacy was not a case of mere 'localism' in the sense of attempting to adopt a local affect or gain admittance to an exclusive group of individuals and organizations deemed 'local.' Rather, it entailed carefully constructing a new, although ultimately limited, mode through which the community could engage constructively with higherscale agencies, organizations, and economic forces.

\section{Conclusion}


Although NGO legitimacy is usually thought of from the perspective of the "outside world" of funders and government interests, we used a micropolitical approach to understand how legitimacy is negotiated within one particular rural community. Our results highlight the legitimacy built between individuals within the organization, the organization as an actor itself, and the vision it promulgates. A micropolitical perspective emphasizes that the actors involved in rural development are heterogeneous and complex, requiring constant careful networking and alliance building to maintain legitimacy and effectiveness. Yet, MARS — and, likely, other similar CBOs - are still highly vulnerable to changes given a lack of diversity in local economies and a lack of power to influence large-scale politics. Thus, a focus on micropolitics demonstrates the ways in which discrete and everyday interpersonal interactions matter to how organizations collaborate and the ways in which macro-political processes manifest in particular places (Mcareavey, 2006).

Here we showed that MARS generated the crucial local legitimacy needed to translate and problem-solve in partnership with and on behalf of rural communities through a combination of individual relationship-building, management of a grounded yet aspirational narrative, and demonstration of effective outcomes. While this corroborates indicators of success in other studies of CBOs and NGOs, a micropolitical perspective reveals the complex ways in which legitimacy is built and expanded on the ground to enable multiscalar connections. However, given the trends towards neoliberalization and a hollowing out of the state in favor of the nonprofit and private sectors, the MARS case echoes what other research has found regarding the contradictory process of devolution. While state and corporate entities come to rely on MARS as a spokes-organization for 'the local' and as a mechanism to fill gaps in public services, the CBO is stretched thin and remains vulnerable (Alexander, 1999; Marwell, 2004; McDermott, 2009), particularly given its dependence on relationships and charisma of just a few people. Thus, while the organization has built a strong base of local legitimacy this only goes so far in its capabilities to address deep-rooted structural issues. Yet, such dynamics illustrate the power of a micropolitical approach in investigating place-based NGOs, and arguably the place-based work of other larger organizations. A focus on the quotidian and embodied interactions of individuals working in particular places - as influenced by their larger structural contexts- can illuminate the ways such organizations generate legitimacy across networks to affect change on the ground.

Acknowledgements: Thanks to Autumn Ellison, Branda Nowell, and Alex Cavanaugh for research help. Many thanks to the interviewees of the Glenwood, Washington area for sharing their time and perspectives. This work was funded by USDA-Agriculture and Food Research Initiative grant \#2011-67023-30111 


\section{References}

Alexander, J., 1999. The impact of devolution on nonprofits: a multiphase study of social service organizations. Nonprofit Management and Leadership, 10(1), pp. 57-70.

Arcand, J.-L. and Wagner, N., 2016. Does community-driven development improve inclusiveness in peasant organizations? - evidence from Senegal. World Development, 78, pp. 105-124. doi:10.1016/j.worlddev.2015.10.016

Armitage, D., 2005. Adaptive capacity and community-based natural resource management. Environmental Management, 35(6), pp. 703-715. doi:10.1007/s00267-004-0076-Z

Atack, I., 1999. Four criteria of development NGO legitimacy. World Development, 27(5), pp. 855-864.

Baker, M. and Kusel, J., 2003. Community Forestry in the United States: Learning from the Past, Crafting the Future. Island Press, Washington, D.C.

Barr, A., Dekker, M., and Fafchamps, M., 2015. The formation of community-based organizations: an analysis of a quasi-experiment in Zimbabwe. World Development, 66, pp. 131-153. doi:10.1016/j.worlddev.2014.08.003

Berkes, F., 2004. Rethinking community-based conservation. Conservation Biology, 18(3), pp. 621-630.

Berkes, F., 2009. Evolution of co-management: role of knowledge generation, bridging organizations and social learning. J Environ Manage, 90(5), pp. 1692-1702. doi:10.1016/j.jenvman.2008.12.001

Blaikie, P., 2006. Is small really beautiful? community-based natural resource management in Malawi and Botswana. World Development, 34(11), pp. 1942-1957. doi:10.1016/j.worlddev.2005.11.023

Bliss, J., Kelly, E., Abrams, J., Bailey, C., and Dyer, J., 2010. Disintegration of the US industrial forest estate: dynamics, trajectories, and questions. Small-Scale Forestry, 9(1), pp. 53-66.

Bodin, Ö and Crona, B., 2008. Management of natural resources at the community level: exploring the role of social capital and leadership in a rural fishing community. World Development, 36(12), pp. 2763-2779.

Bowen, G., 2006. Grounded theory and sensitizing concepts. International Journal of Qualitative Methods, 5(3), pp. 12-23.

Brick, P., Snow, D., and Van de Wettering, S., 2000. Across the Great Divide: Explorations in Collaborative Conservation and the American West. Island Press, Washington, D.C..

Brosius, J., Tsing, A., and Zerner, C., 1998. Representing communities: histories and politics of community - based natural resource management. Society and Natural Resources, 11(2), pp. 157-168. http://doi.org/10.1080/08941929809381069

Brown, L., 1991. Bridging organizations and sustainable development. Human Relations, 44(8), pp. 807-831.

Buscher, B., 2010. Anti-politics as political strategy: neoliberalism and transfrontier conservation in southern Africa. Development and Change, 41(1), pp. 29-51. 
Cash, D., Clark, W., Alcock, F., Dickson, N., Eckley, N., Guston, D., Jäger, J., and Mitchell, R., 2003. Knowledge systems for sustainable development. Proceedings of the National Academy of Sciences of the United States of America, 100(14), pp. 8086-8091.

Cashore, B. and Howlett, M., 2007. Punctuating which equilibrium? understanding thermostatic policy dynamics in Pacific Northwest forestry. American Journal of Political Science, 51(3), pp. 532-551.

Charmaz, K., 2006. Constructing Grounded Theory: A Practical Guide Through Qualitative Analysis. Sage, London.

Cheng, A., Gerlak, A., Dale, L., and Mattor, K., 2015. Examining the adaptability of collaborative governance associated with publicly managed ecosystems over time: insights from the Front Range Roundtable, Colorado, USA. Ecology And Society, 20(1). http://doi.org/10.5751/ES-07187-200135

Cheshire, L., 2010. A corporate responsibility? the constitution of fly-in, fly-out mining companies as governance partners in remote, mine-affected localities. Journal of Rural Studies, 26(1), pp. 12-20.

Collingwood, V., 2006. Non-governmental organisations, power and legitimacy in international society. Review of International Studies, 32(3), pp. 439-454.

Conley, A., and Moote, M. A., 2003. Evaluating collaborative natural resource management. Society and Natural Resources, 16(5), pp. 371-386.

Connelly, S., Richardson, T., and Miles, T., 2006. Situated legitimacy: deliberative arenas and the new rural governance. Journal of Rural Studies, 22(3), pp. 267-277.

Corson, C., 2010. Shifting environmental governance in a neoliberal world: US AID for conservation. Antipode, 42(3), pp. 576-602. doi:10.1111/j.1467-8330.2010.00764.x

Crona, B., and Parker, J., 2012. Learning in support of governance: theories, methods, and a framework to assess how bridging organizations contribute to adaptive resource governance. Ecology and Society, 17(1), 32.

Danks, C., 2008. Institutional arrangements in community-based forestry. In: Donoghue, E. and Sturtevant, V., Editors, 2008. Forest Community Connections: Implications for Research, Management, and Governance. Resources for the Future, Washington, D.C.

Daniels, S. and Walker, G., 1996. Collaborative learning: improving public deliberation in ecosystem-based management. Environmental Impact Assessment Review, 16(2), pp. 71102.

Datta, D., 2007. Sustainability of community-based organizations of the rural poor: learning from Concern's rural development projects, Bangladesh. Community Development Journal, 42(1), pp. 47-62.

Edwards, M., 1999. Legitimacy and values in NGOs and voluntary organizations: some sceptical thoughts. In: Lewis, D., Editor, 1999. International Perspectives on Voluntary Action: Reshaping the Third Sector. Earthscan, London.

Edwards, M., and Hulme, D., 1995. Non-governmental Organisations: Performance and Accountability beyond the Magic Bullet. London, Earthscan. 
Emerson, R., Fretz, R., and Shaw, L., 1995. Writing Ethnographic Fieldnotes. University of Chicago Press, Chicago.

Enzer, M. and Goebel, M., 2014. Place-based conservation finds its voice: a case study of the Rural Voices for Conservation Coalition. In: Charnley, S., Sheridan, T. and Nabhan, G. P., Editors, 2014. Stitching the West Back Together: Conservation of Working Landscapes, University of Chicago Press: Chicago.

Falkner, R., 2003. Private environmental governance and international relations: exploring the links. Global Environmental Politics 3, pp. 72-87.

Fernandez-Gimenez, M., Ballard, H., and Sturtevant, V., 2008. Adaptive management and social learning in collaborative and community-based monitoring: a study of five communitybased forest organizations in the western USA. Ecology and Society, 13(2), 4.

Fredericksen, P. and London, R., 2000. Disconnect in the hollow state: the pivotal role of organizational capacity in community-based development organizations. Public Administrative Review, 60(3), pp. 230-239.

Glasmeier, A. and Farrigan, T., 2005. Understanding community forestry: a qualitative metastudy of the concept, the process, and its potential for poverty alleviation in the United States case. The Geographical Journal, 171(1), pp. 56-69.

Gosnell, H. and Abrams, J., 2011. Amenity migration: diverse conceptualizations of drivers, socioeconomic dimensions, and emerging challenges. GeoJournal 76, pp. 303-322.

Gray, G., Enzer, M., and Kusel, J., Editors, 2001. Understanding Community-based Forest Ecosystem Management. Food Products Press, Binghamton, NY.

Gruber, J., 2010. Key principles of community-based natural resource management: a synthesis and interpretation of identified effective approaches for managing the commons. Environ Manage, 45(1), pp. 52-66.

Hahn, T., Olsson, P., Folke, C., and Johansson, K., 2006. Trust-building, knowledge generation and organizational innovations: the role of a bridging organization for adaptive comanagement of a wetland landscape around Kristianstad, Sweden. Human Ecology, 34(4), pp. 573-592. http://doi.org/10.1007/s10745-006-9035-z

Hardy, C., and Phillips, N., 1998. Strategies of engagement: lessons from the critical examination of collaboration and conflict in an interorganizational domain. Organization Science, 9(2), pp. 217-230.

Hashemi, S. and Hasan, M., 1999. Building NGO legitimacy in Bangladesh: the contested domain. In: Lewis, D., Editor. 1999. International Perspectives on Voluntary Action: Reshaping the Third Sector. Earthscan, London.

Healey, P., De Magalhaes, C., Madanipour, A., and Pendlebury, J., 2003. Place, identity, and local politics: analysing initiatives in deliberative governance. In: Hajer, M. and Wagenaar, H., Editors, 2003. Deliberative Policy Analysis: Understanding Governance in the Network Society. Cambridge University Press, Cambridge.

Hibbard, M. and Lurie, S., 2013. The new natural resource economy: environment and economy in transitional rural communities. Society and Natural Resources, 26(7), pp. 827-844. 
Hiner, C., 2016. Beyond the edge and in between: (re)conceptualizing the rural-urban interface as meaning-model-metaphor. The Professional Geographer, 68(4), pp. 520-532.

Hirt, P., 1994. A Conspiracy of Optimism: Management of the National Forests since World War Two. University of Nebraska Press, Lincoln.

Hodge, I. and Adams, W., 2012. Neoliberalisation, rural land trusts and institutional blending. Geoforum, 43(3), pp. 472-482.

Hurley, P. and Walker, P., 2004. Whose vision? conspiracy theory and land-use planning in Nevada County, California. Environment and Planning A, 36, pp. 1529-1547.

Kelly, E., and Bliss, J., 2009. Healthy forests, healthy communities: an emerging paradigm for natural resource-dependent communities? Society and Natural Resources, 22(6), pp. 519537.

Kusel, J. and Adler, E., 2003. Forest Communities, Community Forests. Bowman and Littlefield, Lanham, MD.

Lähtinen, K., Toppinen, A., Mikkilä, M., Toivio, M., and Suur-Uski, O., 2016. Corporate responsibility reporting in promoting social license to operate in forestry and sawmilling industries. Forestry, 89(5), pp. 525-541.

Lane, M. and Corbett, T., 2005. The tyranny of localism: indigenous participation in communitybased environmental management. Journal of Environmental Policy and Planning, 7(2), pp. 141-159. http://doi.org/10.1080/15239080500338671

Lane, M. and Morrison, T., 2006. Public interest or private agenda? a meditation on the role of NGOs in environmental policy and management in Australia. Journal of Rural Studies, 22(2), pp. 232-242.

Larner, W. and Craig, D., 2005. After neoliberalism? community activism and local partnerships in Aotearoa, New Zealand. Antipode, 37(3), pp. 402-424. http://doi.org/10.1111/j.00664812.2005.00504.x

Leach, M., Mearns, R., and Scoones, I., 1999. Environmental entitlements: dynamics and institutions in community-based natural resource management. World Development, 27(2), pp. 225-247.

Lister, S., 2003. NGO legitimacy - technical issue or social construct? Critique Of Anthropology, 23(2), pp. 175-192.

Little, J. B., 2006. “Timberlands up for grabs.” High Country News, 314. January 23.

Lockie, S. and Higgins, V., 2007. Roll-out neoliberalism and hybrid practices of regulation in Australian agri-environmental governance. Journal of Rural Studies, 23(1), pp. 1-11. http://doi.org/10.1016/j.jrurstud.2006.09.011

Mansuri, G. and Vijayendra, R., 2004. Community-based and -driven development: a critical review. The World Bank Research Observer, 19(1), pp. 1-39. doi:10.1093/wbro/lkh012

Marfo, E., 2007. Institutionalizing citizen participation and community representation in natural resource management: lessons from the Social Responsibility Agreement negotiation in Ghana. Community Development Journal, 43(4), pp. 398-412.

Margerum, R., 2011. Beyond Consensus: Improving Collaborative Planning and Management. 
MIT Press, Cambridge, MA.

Marwell, N., 2004. Privatizing the welfare state: nonprofit community-based organizations as political actors. American Sociological Review, 69(April), pp. 265-291.

Mcareavey, R., 2006. Getting close to the action: the micro-politics of rural development. Sociologia ruralis, 46(2), pp. 85-103.

McCarthy, J., 2002. First World political ecology: lessons from the Wise Use movement. Environment and Planning A, 34(7), pp. 1281-1302.

McCarthy, J., 2005. Devolution in the woods: community forestry as hybrid neoliberalism. Environment and Planning A, 37(6), pp. 995-1014.

McCarthy, J., 2006. Neoliberalism and the politics of alternatives: community forestry in British Columbia and the United States. Annals of the Association of American Geographers, 96(1), pp. 84-104.

McDermott, M., 2009. Locating benefits: decision-spaces, resource access and equity in US community-based forestry. Geoforum, 40(2), pp. 249-259.

McDermott, M., Moote, M. A., and Danks, C., 2011. Effective collaboration: overcoming external obstacles. In: Dukes, E., Firehock, K. and Birkhoff, J., Editors, 2011. CommunityBased Collaboration: Bridging Socio-Ecological Research and Practice. University of Virginia Press, Charlottesville.

Moffat, K. and Zhang, A., 2014. The paths to social licence to operate: an integrative model explaining community acceptance of mining. Resources Policy, 39, pp. 61-70.

Mountjoy, N., Seekamp, E., Davenport, M., and Whiles, M., 2013. The best laid plans: community-based natural resource management (CBNRM) group capacity and planning success. Environmental Management, 52(6), pp. 1547-1561.

Moseley, C. and Charnley, S., 2014. Understanding micro-processes of institutionalization: stewardship contracting and national forest management. Policy Sci, 47, pp. 69-98.

Nelson, P. 2001. Rural restructuring in the American West: land use, family and class discourses. Journal of Rural Studies, 17(4), pp. 395-407.

Newell, P., Pattberg, P., and Schroeder H., 2012. Multiactor governance and the environment. Annual Review of Environment and Resources 37(1), pp. 365.

Ojha, H., Ford, R., Keenan, R., Race, D., Carias Vega, D., Baral, H., and Sapkota, P., 2016. Delocalizing communities: changing forms of community engagement in natural resources governance. World Development, 87, pp. 274-290.

Parkins, J., Dunn, M., Reed, M., and Sinclair, A., 2016. Forest governance as neoliberal strategy: a comparative case study of the Model Forest Program in Canada. Journal of Rural Studies, 45, pp. 270-278. doi:10.1016/j.jrurstud.2016.04.006

Peck, J. and Tickell, A., 2002. Neoliberalizing space. Antipode 34(3), pp. 380-404.

Power, T., 2006. Public timber supply, market adjustments, and local economies: economic assumptions of the Northwest Forest Plan. Conservation Biology, 20(2), pp. 341-350. doi:10.1111/j.1523-1739.2006.00383.x 
Pratten, D., and Ali Baldo, S., 1995. "Return to the roots": processes of legitimacy in Sudanese migrant associations. In: Edwards, M. and Hulme, D., Editors, 1995. Non-Governmental Organizations-Performance and Accountability: Beyond the Magic Bullet. Earthscan, London.

Prudham, W., 1998. Timber and town: post-war federal forest policy, industrial organization, and rural change in Oregon's Illinois Valley. Antipode, 30(2), pp. 177-196.

Purdy, J. M., 2012. A framework for assessing power in collaborative governance processes. Public Administration Review, 72(3), pp. 409-417.

Saxby, J., 1996. Who owns the private aid agencies? In: Sogge, D., Kees, B. and Saxby, J., Editors, 1996. Compassion and Calculation: The Business of Private Foreign Aid. Pluto Press, London.

Smeed, J., Kimber, M., Millwater, J., and Ehrich, L., 2009. Power over, with and through: another look at micropolitics. Leading and Managing, 15(1), pp. 26-41.

Stoddart, M., 2005. The Gramsci-Foucault nexus and environmental sociology. Alternate Routes, 21, pp. $40-63$.

Suchman, M., 1995. Managing legitimacy: strategic and institutional approaches. The Academy of Management Review, 20(3), pp. 571-610.

Suddaby, R., 2006. From the editors: what grounded theory is not. The Academy of Management Journal, 49(4), pp. 633-642.

Takahashi, L., and Smutny, G., 2001. Collaboration among small, community-based organizations: strategies and challenges in turbulent environments. Journal of Planning Education and Research, 21, pp. 141-153.

Thrandardottir, E., 2015. NGO legitimacy: four models. Representation, 51(1), pp. 107-123.

Uphoff, N., 1993. Grassroots organizations and NGOs in rural development: opportunities with diminishing states and expanding markets. World Development, 21(4), pp. 607-622.

Vedder, A., 2007. Questioning the legitimacy of non-governmental organizations. In: Vedder, A., Editor, 2007. NGO Involvement in International Governance and Policy: Sources of Legitimacy. Brill, Leiden.

Walker, E. and McCarthy, J. 2010. Legitimacy, strategy, and resources in the survival of community-based organizations. Social Problems, 57(3), pp. 315-340. doi:10.1525/sp.2010.57.3.315

Walker, P., 2003. Reconsidering "regional" political ecologies: toward a political ecology of the rural American West. Progress in Human Geography, 27(1), pp. 7-24.

Westley, F., 1995. Governing design: the management of social systems and ecosystems management. In: Gunderson, L., Holling, C., and Light, S., Editors. Barriers and Bridges to the Renewal of Ecosystems and Institutions. Columbia University Press, New York.

Winkler, R., Field, D., Luloff, A., Krannich, R., and Williams, T., 2007. Social landscapes of the Inter-Mountain West: a comparison of "old west" and "new west" communities. Rural Sociology, 72(3), pp. 478-501.

Wondolleck, J., 2000. Making Collaboration Work: Lessons from Innovation in Natural 
Resource Management. Island Press, Washington, DC.

Yaffee, S., 1994. The Wisdom of the Spotted Owl: Policy Lessons for a New Century. Island Press, Washington, D.C.

\footnotetext{
${ }^{1}$ We reached theoretical saturation relatively quickly in this case due to the small size of MARS staff and the relatively limited number of organizations with which it interacts closely.

${ }^{2}$ The third author is currently a board member of MARS, though she was not at the time of data collection and analysis.
} 